\title{
Fiscale eenheid en jaarrekening
}

Prof. Dr. M.A. van Hoepen

\section{Inleiding}

De verwerking van de effecten van de fiscale eenheid voor de vennootschapsbelasting in de jaarrekening van ondernemingen is een onderwerp waarvoor in Nederland tot voor kort eigenlijk maar betrekkelijk weinig belangstelling bestond. Uit de wat oudere literatuur vallen te noemen: Van Hoepen (1981)' ${ }^{1}$, Bavinck (1983)', Bruyn $(1984)^{3}$ en Tempelaars en Van Utteren (1985) ${ }^{4}$; deze publikaties handelen voornamelijk over de toerekening van de belastinglast aan de tot de fiscale eenheid behorende deelnemers.

Meer recent is de hiervoor aangeduide problematiek duidelijk sterker in de belangstelling komen te staan. Bijvoorbeeld door de vraag of bij faillissement de curator van een in staat van faillissement verkerende vennootschap die tot een fiscale eenheid behoort, nog bedragen kan claimen wegens door de fiscale eenheid in het verleden genoten voordelen van horizontale compensatie van verliezen, die in feite door de thans faillerende vennootschap zijn gegenereerd. Of in een gelijksoortige situatie wegens in principe in de fiscale eenheid achterblijvende potentiële voordelen van voorwaartse compensatie van verliezen die door de thans faillerende vennootschap zijn gegenereerd. Ook de toenmalige suggestie van de heer Vreugdenhil, dat de toerekening van de baten uit hoofde van horizontale verliescompensatie in de fiscale eenheid aan de verliesgevende maatschappij mogelijk wettelijk geregeld zou moeten worden, heeft aan die verhoogde belangstelling bijgedragen. ${ }^{5}$ Die toegenomen aandacht is niet alleen in de literatuur tot uitdrukking gekomen ${ }^{6}$, maar heeft ook geleid tot aandacht voor dit vraagstuk in de regelgeving te onzent. In Aflevering 12 van de Richtlijnen voor de Jaarverslaggeving van mei 1992 besteedt de RJ voor het eerst aandacht aan dit vraagstuk. ${ }^{7}$ Mede is (her)nieuw(d)e aandacht voor dit vraagstuk mijns inziens relevant geworden door de nieuwe toets van redelijkheid en billijkheid en de mogelijke onrechtmatige verrijking (Boek $3 \mathrm{BW}$ ).

In de VS geniet de verrekening van de belastinglast tussen de tot een fiscale eenheid behorende ondernemingen al veel langer dan te onzent een uitgebreide belangstelling, zodanig zelfs dat er hele boeken over vol geschreven zijn. ${ }^{8}$ Men is op het eerste gezicht geneigd zulks op het conto van een hogere claimgerichtheid en hogere 'lawyer'dichtheid aldaar te schrijven. Wat daar ook van zij, niet vergeten moet worden dat in de VS het onder bepaalde voorwaarden mogelijk is een fiscale eenheid te vormen bij een kapitaalparticipatie van minimaal $80 \%$. In zodanig geval is het dus essentieel vast te stellen aan wie het voordeel van de verliescompensatie in de fiscale eenheid toevalt, aan de meerderheidsaandeelhouder (de moedermaatschappij) of aan de minderheidsaandeelhouder(s) van de verlies-dochter, of dat dit voordeel tussen beiden verdeeld moet worden. En zo dat laatste het geval is welke verdeelsleutel dan gehanteerd kan/moet worden.

Naast een behandeling van die verdeelproblematiek, die neerkomt op de toerekening van de belastinglast tussen de deelnemers van de fiscale eenheid (een probleem voor de vennootschappe-

Prof. Dr. M.A. van Hoepen, doctoraal Bedrijfseconomie, NEH 1972. Accountantsexamen EUR 1975. Promotie 1981. Hoogleraar Bedrijfshuishoudkunde en Accountancy EUR. Vennoot Deloitte \& Touche. Raad-plaatsvervanger Ondernemingskamer. Lid Raad van de Jaarverslaggeving. 
lijke jaarrekening dus), is het tevens relevant na te gaan wat de consequenties zijn van het bestaan van de fiscale eenheid voor de verwerking van de belastinglast in de geconsolideerde jaarrekening. Alvorens daar toe over te gaan is het dan goed de verhouding tussen het fiscaalrechtelijk groepsbegrip (de fiscale eenheid voor de $\mathrm{Vpb}$ ) en het vennootschapsrechtelijk groepsbegrip (de consolidatiekring) kort te beschouwen.

\section{Fiscaalrechtelijk en vennootschapsrechtelijk groepsbegrip}

Het groepsbegrip voor het jaarrekeningrecht is gedefinieerd in BW2: artikel 24b: 'Een groep is een economische eenheid waarin rechtspersonen en vennootschappen organisatorisch zijn verbonden. Groepsmaatschappijen zijn rechtspersonen en vennootschappen die met elkaar in een groep zijn verbonden'. De RJ ${ }^{9}$ heeft dit enigszins vage begrip wat nader geconcretiseerd door elementen aan te geven die kunnen doen besluiten tot het bestaan van een groepsband, zoals:

- complementariteit van economische activiteiten;

- gemeenschappelijkheid van financieel en economisch beleid en beheer;

- fiscale verbondenheid (het bestaan van een fiscale eenheid);

- aansprakelijkstellingen over en weer.

Zoals bekend is met de Aanpassingswet Zevende Richtlijn de notie van het bestaan van een centrale leiding uit het groepsbegrip verdwenen. Naar algemeen gevoelen moet daaraan geen al te grote betekenis worden toegekend, immers:

- het begrip groepsmaatschappij is, althans voor kapitaalvennootschappen, veel dichter bij het begrip dochtermaatschappij komen te staan en voor een dochtermaatschappij is in principe de mogelijkheid van overheersende zeggenschap noodzakelijk;

- vele voor een groepsband relevante elementen impliceren een centrale leiding (bijvoorbeeld gemeenschappelijkheid van financieel en economisch beleid en beheer);
- in de Zevende Richtlijn is het element van centrale leiding wel degelijk aanwezig (artikelen 12 en 13, 7e Richtlijn).

Het is niet de bedoeling van deze bijdrage het vennootschapsrechtelijk groepsbegrip breed uit te meten. Voor deze bijdrage volstaat het te concluderen dat vennootschapsrechtelijk gezien groepsbanden kunnen bestaan tussen allerlei rechtspersonen en vennootschappen (kapitaalvennootschappen, personenvennootschappen, vennootschappen naar buitenlands recht, maar bijvoorbeeld ook verenigingen), dat voor een groepsband middellijke of onmiddellijke kapitaalparticipatie niet is vereist, en dat voor een groepsband de concrete situatie beslissend is, met andere woorden men kan niet vrijelijk voor het bestaan van een groepsband kiezen.

Weliswaar hoeft er voor het fiscale groepsbegrip geen enkele notie van enige centrale leiding te bestaan, maar niettemin is het fiscale groepsbegrip van artikel $15 \mathrm{Vpb}$ duidelijk enger dan het vennootschappelijke:

- de moedermaatschappij moet (behoudens enkele hier niet ter zake doende uitzonderingen) een in Nederland gevestigde NV, BV, coöperatie of onderling waarborgmaatschappij zijn;

- de dochtermaatschappij moet (behoudens enkele hier niet ter zake doende uitzonderingen) een in Nederland gevestigde NV of BV zijn;

- er moet sprake zijn van een kapitaalparticipatie van $99 \%$ of meer van de niet-zoekgeraakte aandelen en in geval van certificering van aandelen wordt in principe niet aan deze bezitseis voldaan;

- tenslotte dient te worden geconstateerd dat de fiscale eenheid een kwestie van vrijwilligheid is, de fiscale eenheid wordt slechts op gemeenschappelijk verzoek van de deelnemers toegekend; voor het verbreken van de fiscale eenheid bestaan meer mogelijkheden, behoudens door verzoek, kan de fiscale eenheid worden beëindigd door verkoop of emissie van aandelen waardoor niet meer aan de bezitseis wordt voldaan. 


\section{MAB}

Evenmin als voor het vennootschapsrechtelijk groepsbegrip is het de bedoeling het fiscaalrechtelijk groepsbegrip breed uit te meten. De voorgaande beschrijving is voldoende om te constateren dat het fiscaalrechtelijke groepsbegrip (verder de fiscale eenheid) en het vennootschapsrechtelijk groepsbegrip (de consolidatiekring, verder ook de groep) geenszins identiek zijn. Bijgevolg zijn er drie situaties te onderscheiden.

A De fiscale eenheid en de consolidatiekring dekken elkaar volledig af, doordat:

A-1 de fiscale eenheid en de consolidatiekring identiek zijn (kort aangegeven: Cons. = FE);

A-2 de consolidatiekring uit meerdere fiscale eenheden bestaat, doch alle in die fiscale eenheden opgenomen maatschappijen deel uitmaken van de consolidatiekring (kort aangegeven: Cons. $=\Sigma F E$ );

A-3 de fiscale eenheid uit meerdere consolidatiekringen bestaat ( $F E=\Sigma$ Cons.); deze situatie vergt geen afzonderlijke bespreking, aangezien de problematiek hierbij niet principieel anders ligt dan bij de verdeling van de belastinglast over de verschillende deelnemers aan de fiscale eenheid.

B De consolidatiekring is ruimer dan de fiscale eenheid (Cons. > FE).

C De consolidatiekring is beperkter dan de fiscale eenheid (Cons. < FE).

Deze indeling vormt de grondslag voor de hierna volgende beschouwing over de verwerking van de belastinglast in de geconsolideerde jaarrekening.

\section{De verwerking van belasting naar de winst in de geconsolideerde jaarrekening}

Op grond van BW2: artikel 410, lid 1 moet, afgezien van een aantal voor dit onderwerp niet relevante uitzonderingen, de geconsolideerde jaarrekening aan dezelfde algemene en specifieke eisen voldoen als de vennootschappelijke jaarrekening. Voor deze beschouwing relevant zijn derhalve:
- de verplichting tot 'segmentatie' van belasting over het resultaat uit de gewone bedrijtsuitoefening en de belasting over het buitengewone resultaat (BW2: artikel 377, lid 1);

- de verplichting tot 'deferred-tax accounting' (BW2: artikel 362, lid 5);

- de wenselijkheid van toelichting indien de effectieve belastingdruk afwijkt van de voor de onderneming als normaal te beschouwen belastingdruk (Richtlijnen, alinea 2.53-523).

\section{$A$ Cons. $=$ FE of Cons. $=\Sigma F E$}

In de hiervoor onder A geschetste situaties, waarin de consolidatiekring en de fiscale eenheid (-heden) elkaar perfect overlappen, rijzen met betrekking tot de verwerking van de belastinglast in de geconsolideerde jaarrekening weinig problemen.

In de situatie A-1, waarin de fiscale eenheid en de consolidatiekring identiek zijn, is de belastinglast die in de geconsolideerde jaarrekening wordt opgenomen precies de belastinglast die 'behoort' bij het geconsolideerd resultaat. In de geconsolideerde jaarrekening zijn alle 'intercompany-verhoudingen' geëlimineerd; dat zijn ze ook in de fiscale eenheid. Ook de voorwaarden die gesteld kunnen worden bij het verwerken van actieve belastinglatenties (redelijkerwijs geen twijfel aan realisatie, of bij twijfel aan realisatie de mogelijkheid van verrekening met passieve latenties ${ }^{10}$ ) dienen geconsolideerd te worden beschouwd. Het verdient opmerking, dat het feit dat de verwezenlijking van bepaalde actieve latenties van deelnemers aan de fiscale eenheid niet aan twijfel onderhevig kan worden geacht door mogelijkheden van compensatie met passieve latenties van andere deelnemers. Echter, deze en soortgelijke vragen scheppen geen problemen voor de geconsolideerde jaarrekening, doch voor de vennootschappelijke jaarrekening van de deelnemers aan de fiscale eenheid.

Indien de consolidatiekring uit meer dan één fiscale eenheid bestaat $(A-2$ : Cons. $=\Sigma F E)$ zal in veel gevallen een toelichting op de daarin opgenomen belastinglast nodig zijn. Immers, tussen de verschillende fiscale eenheden kunnen 'intercompanyverhoudingen' bestaan die geconsolideerd zijn 
geëlimineerd. Ook bestaat de mogelijkheid dat bijvoorbeeld actieve belastinglatenties geconsolideerd niet zijn opgenomen omdat ze zijn opgekomen in de ene fiscale eenheid en niet kunnen worden gecompenseerd met de passieve latenties van de andere fiscale eenheid. Deze problematiek is evenwel niet wezenlijk anders dan die bij consolidatie van niet tot een fiscale eenheid behorende groepsmaatschappijen.

\section{$B$ Cons. $>F E$}

Indien de consolidatiekring ruimer is dan de fiscale eenheid doen zich voor de geconsolideerde jaarrekening ook weinig andere problemen voor, dan dat eventueel de belastinglast in de geconsolideerde jaarrekening toelichting behoeft, op grond van dezelfde overwegingen als hiervoor in situatie A-2 (Cons. $=\sum F E$ ) vermeld. Hoewel dit niet specifiek is voor de hier geschetste situatie wil ik in dit verband wel aandacht vragen voor de samenhang tussen de hoofdelijke aansprakelijkstelling volgens BW2: artikel 403 en de fiscale eenheid. Dit is een vraag die zich ook in de hier bedoelde situatie kan voordoen. De vraag namelijk of indien een niet in de fiscale eenheid opgenomen rechtspersoon zich conform BW2: artikel 403 hoofdelijk aansprakelijk stelt voor een wel in de fiscale eenheid opgenomen rechtspersoon, deze aansprakelijkheid zich ook uitstrekt tot de belastingschuld van de fiscale eenheid. Van der Well is van mening dat zulks niet het geval is, immers het verschuldigd geraken van belasting vloeit niet uit een rechtshandeling voort (en slechts tot zodanige schulden strekt de aansprakelijkheid ex BW2: artikel 403 zich uit). Ik ben van mening dat hier echter wel sprake is van aansprakelijkheid. De aansprakelijkheid die hier bedoeld is, geldt voor 'uit rechtshandelingen van de rechtspersoon voortvloeiende schulden' en het bestaan van een fiscale eenheid is een bewust door een rechtshandeling in het leven geroepen situatie. ${ }^{12}$

\section{$C$ Cons. $<F E$}

Ook in de situatie dat de consolidatiekring beperkter is dan de fiscale eenheid kan de geconsolideerde belastingpositie toelichting behoeven, bijvoorbeeld omdat in de geconsolideerde jaarrekening verhoudingen met derden zijn opgenomen die in de (ruimere) fiscale eenheid als 'intercompany-verhoudingen' zijn geëlimineerd. Ook kan die noodzaak ontstaan omdat de geconsolideerde winst fiscaal gezien middels horizontale verliescompensatie wordt 'opgesoupeerd' door buiten de consolidatiekring vallende deelnemers aan de fiscale eenheid die verliesgevend zijn.

Een ander attentiepunt in de hier geschetste situatie is dat de deelnemers aan de fiscale eenheid hoofdelijk aansprakelijk zijn voor de belastingschuld van de fiscale eenheid. Voor de geconsolideerde jaarrekening betekent dat, nu de aansprakelijkheid voor de belastingschuld zich verder uitstrekt dan de grenzen van de groep, vermelding van die aansprakelijkheid nodig zal zijn. Datzelfde geldt uiteraard voor de vermelding daarvan in de vennootschappelijke jaarrekening van de deelnemers aan de fiscale eenheid, omdat daarvoor geldt dat de (hoofdelijke) aansprakelijkheid voor de belastingschuld (van de fiscale eenheid) op een ander niveau zal liggen dan de in die jaarrekening opgenomen belastingschuld.

Er rijst in de hier geschetste situatie nog een probleem, namelijk dat de belastinglast (althans de verschuldigde belasting) wordt berekend op basis van het resultaat van de (ruimere) fiscale eenheid, terwijl de bij het geconsolideerd resultaat behorende belastinglast die is welke toegerekend moet worden aan de (beperkter) consolidatiekring. Dit roept dus de vraag op welk deel van de belasting van de fiscale eenheid toegerekend moet worden aan de groep en welk deel aan de buiten de groep vallende deelnemers aan de fiscale eenheid. Deze vraag is uiteraard ten principale niet anders dan de vraag hoe de belasting over de vennootschappelijke jaarrekeningen van de deelnemers aan een fiscale eenheid 'verdeeld' moet worden.

\section{De verwerking van de belasting naar de winst in de vennootschappelijke jaarrekening van deelnemers aan de fiscale eenheid}

Voor de oplossing van het zojuist geschetste pro- 
bleem vallen drie hoofdrichtingen te onderscheiden:

1 De belastinglast wordt niet toegerekend, doch volledig gedragen c.q. verantwoord door het hoofd van de fiscale eenheid/consolidatiekring (verder aan te duiden als de moedermaatschappij).

2 De belastinglast wordt toegerekend aan de deelnemers van de fiscale eenheid volgens een bepaalde verdeelsleutel.

3 De moedermaatschappij stelt zich op als ware zij fiscus en verrekent de belastinglast met de dochtermaatschappijen als waren ze zelfstandig belastingplichtig (hoewel ook hier sprake is van toerekening, de belastingschuld wordt immers bepaald alsof er slechts één belastingplichtig lichaam was, wordt deze methode toch afzonderlijk behandeld).

\section{Ad 1 Moeder verantwoordt de belastinglast}

Deze oplossing is in de uitwerking tamelijk eenduidig. Ter illustratie moge het volgende voorbeeld dienen:

\section{Voorbeeld 1}

Een moedermaatschappij (M) vormt met haar dochters $B$ en $D$ een groep. De gevormde fiscale eenheid bestaat behalve $M$ uit de dochters $B$ en $C$. De 'eigen' resultaten van $M, B, C$ en $D$ zijn respectievelijk $100,60,(10)$ en 40 . Het belastingtarief bedraagt $40 \%$.

\section{Uitwerking}

Indien $\mathrm{M}$ de gehele op de fiscale eenheid rustende belastinglast zou verantwoorden zouden de winsten verliesrekeningen als volgt komen te luiden:

\begin{tabular}{|c|c|c|c|c|c|}
\hline & $\mathrm{M} \mathrm{gr/fe}$ & $\mathrm{B} \mathrm{gr/fe}$ & $\mathrm{C} \overline{\mathrm{g} r} / \mathrm{fe}$ & $\mathrm{Dgr} / \mathrm{fe}$ & Cons. \\
\hline \multirow{3}{*}{$\begin{array}{l}\text { 'eigen' resultaat } \\
\text { belasting" }\end{array}$} & 100 & 60 & (10) & 40 & 200 \\
\hline & 60 & 0 & 0 & 16 & 76 \\
\hline & 40 & 60 & (10) & 24 & 124 \\
\hline \multirow[t]{2}{*}{ resultaat deeln. } & 74 & & & & (10) \\
\hline & 114 & & & & 114 \\
\hline
\end{tabular}

$* 150 \times 0,4$
De geconsolideerde winst- en verliesrekening, alsmede de vennootschappelijke winst- en verliesrekeningen van $M, B$ en $C$ tonen nu een belastinglast die niet te rijmen valt met het nominale tarief van $40 \%$. Bovendien wordt zowel voor $M$ als geconsolideerd een onjuiste indruk gegeven van de rentabiliteit van de eigen activiteiten ten opzichte van die van de deelnemingen. Dit wordt veroorzaakt door het feit dat het voordeel van de mogelijkheid van horizontale verliescompensatie van de niet tot de groep (maar wel tot de fiscale eenheid) behorende maatschappij $C$ 'onderduikt' in de belasting over het 'gewone' (dat wil zeggen 'eigen') resultaat van $M$. In verband met dit laatste schrijft de RJ voor dat in de winst- en verliesrekening van de moeder de belastinglast dient te worden toegerekend aan de eigen activiteiten en aan de deelnemingen. ${ }^{13}$

Alsdan zou in voorbeeld 1 de winst- en verliesrekening van $M$ vennootschappelijk en geconsolideerd het volgende beeld geven:

\begin{tabular}{|c|c|c|c|c|}
\hline & $M$ & & Cons. & \\
\hline $\begin{array}{l}\text { 'eigen' resultaat } \\
\text { belasting }\end{array}$ & $\begin{array}{r}100 \\
40\end{array}$ & & $\begin{array}{r}200 \\
80\end{array}$ & \\
\hline \multirow[t]{3}{*}{$\begin{array}{l}\text { resultaat deelnemingen } \\
\text { belasting }\end{array}$} & $\begin{array}{l}90 \\
36 \\
\end{array}$ & 60 & $\begin{array}{r}(10) \\
(4) \\
-\end{array}$ & 120 \\
\hline & & 54 & & (6) \\
\hline & & 114 & & 114 \\
\hline
\end{tabular}

De hier geillustreerde oplossing zou te rechtvaardigen zijn door de stelling, dat de dochtermaatschappijen die in de fiscale eenheid zijn opgenomen geen zelfstandige relatie met de fiscus hebben. De toerekening aan $\mathrm{M}$ kan bovendien op een onderlinge afspraak berusten. Niettemin kan bezwaarlijk staande worden gehouden dat deze wijze van toerekening er een 'at-arm's-length' basis is. Daardoor is het niet denkbeeldig, dat wanneer de afspraak over de toerekening van het voordeel van horizontale verliescompensatie aan $M$ in het zicht van het faillissement van $C$ is gemaakt (en $C$ tijdig voor het faillissement 'ontvoegd' is uit de fiscale eenheid), zodanige hande- 
ling als paulianeus bestempeld zou kunnen worden. Doch zelfs al zou deze afspraak niet in het zicht van faillissement zijn gemaakt, dan nog is het twijfelachtig of deze afspraak de toets van redelijkheid en billijkheid van (het nieuwe) Boek 3 BW zou kunnen doorstaan. Hetzelfde geldt voor de vraag of er geen sprake is van onrechtmatige verrijking.

\section{Ad 2 Toerekening volgens een verdeelsleutel}

In de al eerder aangehaalde ontwerp-Richtlijn 2.53 .5 (aflevering 12, mei 1992) noemt de RJ in deze categorie twee varianten:

- a 'de moeder rekent af op basis van het commercieel resultaat van de dochter';

- $b$ 'de moeder rekent af op basis van het fiscaal resultaat van de dochter ...'.

Naar mijn indruk komt de onder a genoemde variant in de praktijk vaker voor dan de variant onder $b$. Het is wellicht niet ondienstig beide varianten aan de hand van een voorbeeld te illustreren. Terwille van de eenvoud ga ik hierbij en bij de verdere illustraties uit van een voorbeeld waarbij de consolidatiekring samenvalt met de fiscale eenheid.

\section{Voorbeeld 2}

$M$ vormt met haar groepsmaatschappijen B en $C$ een fiscale eenheid. De 'eigen resultaten van de maatschappijen bedragen respectievelijk 500, (300) en 200.

Bij $B$ is de kostprijs van de verkopen voor fiscale doeleinden 100 hoger dan vennootschappelijk (een tijdelijk verschil leidend tot een passieve belastinglatentie). Het belastingtarief bedraagt $40 \%$. Indien de moeder af zou rekenen op basis van het commercieel resultaat zouden de respectievelijke winst- en verliesrekeningen als volgt komen te luiden:

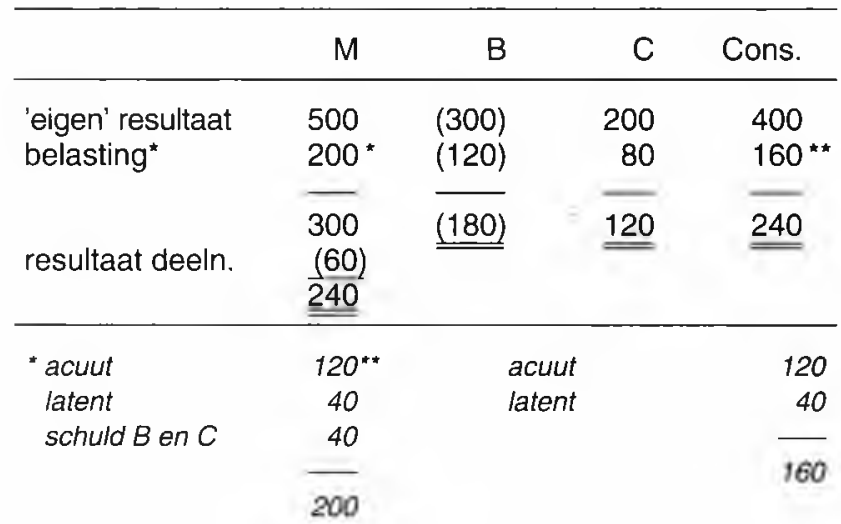

Bij deze oplossing komt bij B geen passieve belastinglatentie voor, hoewel de onderneming deze wel genereert. Deze belastinglatentie 'duikt als het ware onder' in de (rekening-courant) verhouding tussen $M$ en $B$. Dit niet verwerken van de latente belastingpositie in de vennootschappelijke jaarrekening van de dochter zou als een nadeel kunnen worden gezien. Een andere mogelijk als nadeel te appreciëren eigenschap van deze methode is dat verliesdochters automatisch het voordeel van verliescompensatie in de schoot krijgen geworpen, terwijl dat voordeel voor de groep/fiscale eenheid geenszins zeker behoeft te zijn en mogelijk zelfs door verliesverdamping niet eens zal ontstaan. In elk geval wordt in voorbeeld 2 bij deze methode aan $B$ een bate toegerekend (automatische verliescompensatie) die deze mogelijkerwijs als zelfstandig belastingplichtige niet had kunnen realiseren. De vordering van $B$ op $M$ roept bovendien het gevaar op dat de curator bij een eventueel faillissement van $B$ deze vordering zal komen innen bij M. ${ }^{14}$

In de tweede door de RJ genoemde variant van toerekening zou uitgaande van de cijfers van voorbeeld 2 de uitwerking als volgt kunnen luiden: 


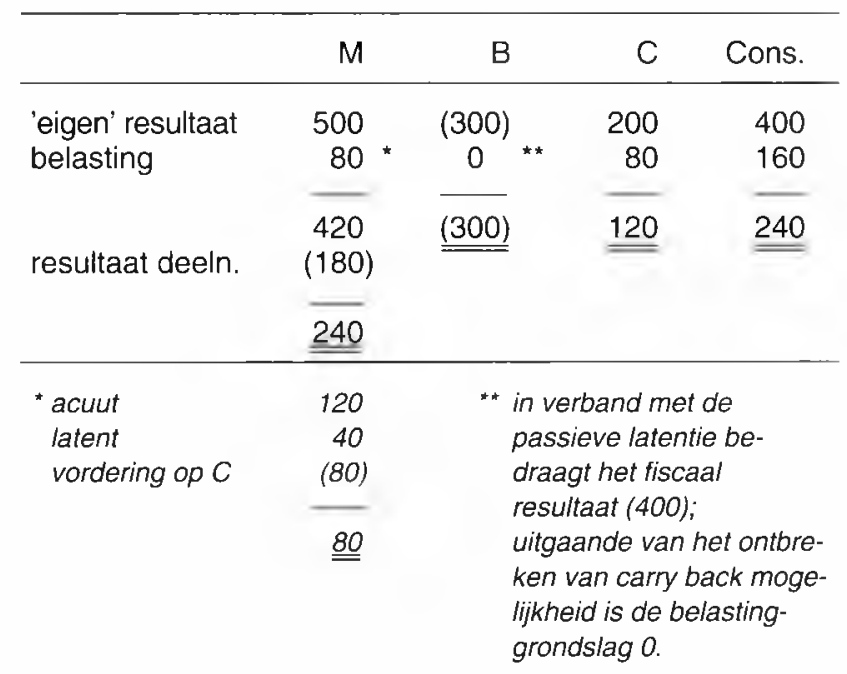

Ook bij deze oplossing komt bij B geen passieve belastinglatentie voor, maar in tegenstelling tot de oplossing volgens $2 a$ 'duikt deze ook niet onder' in de rekening-courant verhouding tussen $M$ en $B$, doch in de belastinglast over het 'eigen' resultaat dat $\mathrm{M}$ presenteert. Het is ten zeerste de vraag of de winst- en verliesrekening van $M$ hiermee aan het inzichtvereiste voldoet. Dit probleem zou voor $M$ opgelost kunnen worden met het eerder genoemde voorschrift van de RJ, inhoudende dat de belastinglast in de winst- en verliesrekening van de moeder dient te worden toegerekend aan de eigen activiteiten en aan de deelnemingen. Voor het inzicht dat de vennootschappelijke jaarrekening van $\mathrm{B}$ dient te geven biedt dit echter geen soelaas. Ook al kan de belastinglast bij $B$ worden gerechtvaardigd op grond van de overweging dat de hier bedoelde wijze van toerekenen contractueel is overeengekomen, dan nog geldt dat deze toerekening zeker niet 'at-arm's-length' basis is. Bovendien rijst bij deze oplossing de vraag hoe gehandeld dient te worden als $\mathrm{B}$ in komende jaren zodanige fiscale resultaten behaalt, dat zij het eens geleden verlies (ook als zelfstandig belastingplichtige) verticaal zou hebben kunnen compenseren.

Toerekening van de belastinglast als 'kip-of-ei' vraagstuk

In wezen is de verdeling van de belastinglast over de deelnemers aan een fiscale eenheid in geval van verliescompensatie een 'kip-of-ei' vraagstuk. Men kan zich op het standpunt stellen, dat het voordeel van verliescompensatie wordt:

- veroorzaakt door het verlies van de verliesgevende deelnemers;

- veroorzaakt door de winst van winstgevende deelnemers;

- veroorzaakt door het feit dat de moedermaatschappij als (nagenoeg) 100\% aandeelhouder de fiscale eenheid heeft tot stand gebracht.

Het eerste uitgangspunt wordt feitelijk gehanteerd indien de belastingtoerekening plaatsvindt op basis van het commercieel resultaat (uitwerking 2.a in het voorgaande).

Het tweede uitgangspunt wordt gehanteerd bij een in de VS wel gebruikte methode die daar bekend staat als 'allocation to the profit-members'. ${ }^{15}$ Indien in ons voorbeeld het (vennootschappelijke) verlies van $B$ aan $M$ en $C$ zou worden toegerekend (naar evenredigheid van hun 'eigen' vennootschappelijke winst) zou het volgende beeld ontstaan:

\begin{tabular}{|c|c|c|c|c|}
\hline & $M$ & B & $\mathrm{C}$ & Cons. \\
\hline \multirow{2}{*}{$\begin{array}{l}\text { 'eigen' resultaat } \\
\text { belasting }\end{array}$} & 500 & $(300)$ & 200 & 400 \\
\hline & $114^{*}$ & 0 & $46^{\star \star}$ & 160 \\
\hline \multirow{3}{*}{ resultaat deeln. } & 386 & $(300)$ & 154 & 240 \\
\hline & $(146)$ & & & \\
\hline & 240 & & & \\
\hline
\end{tabular}

* $0,4 \times 500-5 / 7 \times 0,4 \times 300$

** $0,4 \times 200-2 / 7 \times 0,4 \times 300$

De bezwaren die tegen deze toerekeningsmethode kunnen worden aangevoerd zijn min of meer gelijkluidend aan die welke genoemd zijn tegen de eerdergenoemde afrekeningsmethode. Bij de hier gegeven uitwerking is ook de passieve belastinglatentie van $\mathrm{B}$ impliciet over de 'profitmembers' verdeeld.

Een andere in de VS wel gehanteerde toerekeningsmethode is die waarbij het 'fiscale verlies' (bij B een resultaat van $-/-400$ ) over de 'profitmembers' wordt verdeeld en niet de uitgestelde belasting van $40(0,4 \times 100){ }^{16}$ 
Het als derde genoemde uitgangspunt (toerekening aan de moedermaatschappij omdat zij de fiscale eenheid is aangegaan) wordt feitelijk gehanteerd indien de belastingtoerekening plaatsvindt op basis van het fiscaal resultaat (uitwerking $2 \mathrm{~b}$ in het voorgaande).

\section{Ad 3 Moeder treedt op als fiscus}

Op het eerste gezicht lijkt de verrekeningsmethode waarbij de moeder zich opstelt als ware zij fiscus de meest voor de hand liggende en meest reële methode. Enerzijds worden aan de dochtermaatschappijen geen voordelen onthouden of toegerekend die zij als zelfstandig belastingplichtige zouden hebben genoten of juist niet zouden-hebben genoten. In die zin is de verhouding met de dochtermaatschappijen 'at-arm's-length'. Anderzijds wordt het onloochenbaar uitgangspunt recht gedaan, dat slechts de moedermaatschappij door haar aandelenbezit de fiscale eenheid kan initiëren, doordat de voordelen van de fiscale eenheid haar worden toegerekend voor zover de dochtermaatschappijen die niet zelfstandig zouden kunnen hebben verwerven. ${ }^{17}$

In ons voorbeeld zou de uitwerking van deze methode als volgt kunnen zijn:

\begin{tabular}{|c|c|c|c|c|}
\hline & $M$ & B & $\mathrm{C}$ & Cons. \\
\hline $\begin{array}{l}\text { 'eigen' resultaat } \\
\text { belasting }\end{array}$ & $\begin{array}{l}500 \\
200\end{array}$ & $\begin{array}{l}(300) \\
(120)\end{array}$ & $\begin{array}{r}200 \\
80\end{array}$ & $\begin{array}{l}400 \\
160\end{array}$ \\
\hline resultaat deeln. & $\begin{array}{c}300 \\
(60)\end{array}$ & $(180)$ & 120 & 240 \\
\hline & 240 & & & \\
\hline
\end{tabular}

Hierbij is verondersteld, dat B (zelfstandig) geen mogelijkheid tot achterwaartse verliescompensatie heeft. Daarnaast is er van uitgegaan dat voor $B$ de voorwaartse verlies-compensatie niet aan twijfel onderhevig is. $B$ rekent dus met $M$ af op basis van het fiscaal resultaat $(-/-400)$ derhalve een belastingbedrag van nihil. De negatieve belastinglast (ad 120) bij $\mathrm{B}$ bestaat derhalve uit:
- een actieve belastinglatentie uit hoofde van het recht op voorwaartse verliescompensatie: $0,4 \times(400)=$

- een passieve belastinglatentie uit hoofde van het verschil in voorraadwaardering; $0,4 \times 100=$

Bij deze veronderstellingen is de uitkomst van ons voorbeeld gelijk aan die waarbij de moedermaatschappij afrekent op basis van het commercieel resultaat (methode 2.a in het voorgaande).

Indien echter voor B de voorwaartse verliescompensatie niet boven elke twijfel verheven wordt geacht en B slechts een actieve latentie uit hoofde van voorwaartse verliescompensatie opneemt (of dient op te nemen volgens de RJ) voor zover die gecompenseerd kan worden met de passieve latentie uit hoofde van het verschil in voorraadwaardering ontstaat het volgende beeld:

\begin{tabular}{lccrc}
\hline & $\mathrm{M}$ & $\mathrm{B}$ & $\mathrm{C}$ & Cons. \\
\hline 'eigen' resultaat & 500 & $(300)$ & 200 & 400 \\
belasting & $\underline{120}$ & $\underline{(40)}$ & $\underline{80}$ & 160 \\
& $\underline{380}$ & $\underline{\underline{(260)}}$ & $\underline{\underline{120}}$ & $\underline{\underline{240}}$ \\
resultaat deeln. & $\underline{\underline{(140)}}$ & & & \\
\hline
\end{tabular}

Hierbij is verondersteld dat de passieve belastinglatentie bij $\mathrm{B}$ binnen de periode van voorwaartse verliescompensatie tot omkering komt. B verrekent niets met $M$ en haar negatieve belastinglast ( $\mathrm{ad} 40$ ) is als volgt opgebouwd:

- maximale actieve latentie uit hoofde van carryforward : $0,4 \times(400)=$

- niet 'erkend' in verband met twijfel over carryforward

- actieve latentie compensabel

met passieve latentie

De inzichtelijkheid van de resultatenrekening van $M$ zou verhoogd kunnen worden, door toepassing van de RJ-suggestie om de belasting afzonderlijk toe te rekenen aan de eigen activiteiten en die van deelnemingen. ${ }^{18}$

De resultatenrekening van $\mathrm{M}$ zou dan worden: 


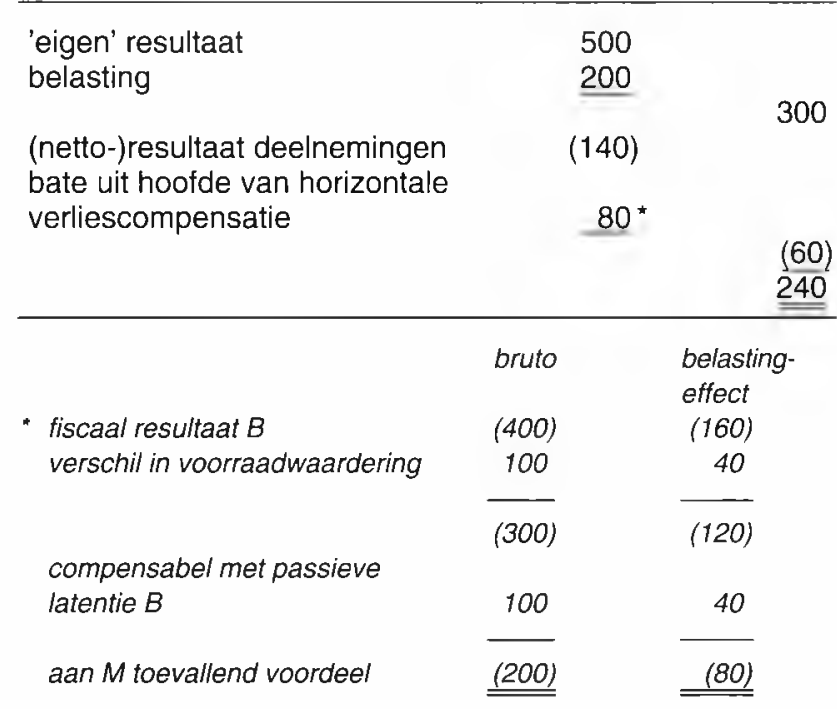

Zoals gezegd lijkt de methode waarbij de moedermaatschappij zich opstelt als ware zij fiscus op het eerste gezicht het meest zuiver. Het is evenwel goed zich te realiseren dat de hierdoor geïmpliceerde fiscale zelfstandigheid van de dochtermaatschappijen niets anders dan een fictie is. De dochtermaatschappijen in de fiscale eenheid/groep kunnen niet hun eigen 'belasting-politiek' voeren. Zo zou in ons voorbeeld B als zelfstandig belastingplichtige bij dreigende verliesverdamping ertoe over kunnen gaan om stille reserves te realiseren teneinde de verliescompensatie zeker te stellen. Binnen de fiscale eenheid/groep bestaat daar echter geen enkele behoefte toe omdat het verlies van $\mathrm{B}$ allang door horizontale compensatie is verrekend. Ook eenzijdige fiscale stelselwijziging bij de dochtermaatschappijen (met als doel verliesverdamping te voorkomen) is uitgesloten, zij zijn gebonden aan de waarderings- en winstbepalingsgrondslagen van de fiscale eenheid (in casu de moedermaatschappij). Soortgelijke bedenkingen kunnen wellicht aangevoerd worden tegen de binnen de groep/fiscale eenheid gehanteerde interne verrekenprijzen. De verrekenprijzen voor bijvoorbeeld halffabrikaten die $\mathrm{B}$ aan $\mathrm{C}$ levert behoeven geenszins 'at arm's-length' te zijn, waardoor B als bestendig verliesgevend naar voren komt, maar de winst bij $C$ 'valt'. Men zou de vraag kunnen stellen of $B$ (als juridisch zelfstandige rechtspersoon) in zo'n situatie dan niet zou behoren te profiteren van de voordelen van horizontale verliescompensatie, nu zij toch ook hoofdelijk aansprakelijk is voor de belastingschuld van de gehele groep/fiscale eenheid.

\section{Slotbeschouwing}

De verwerking van de winstbelasting in de geconsolideerde jaarrekening bij het bestaan van een fiscale eenheid roept geen bijzondere problemen op. Wel zal in veel gevallen de belastinglast toelichting behoeven omdat deze door het niet samenvallen van fiscale eenheid en consolidatiekring in veel gevallen zal afwijken van de te verwachten effectieve belastingdruk.

De verdeling van de belastinglast over de deelnemers aan de fiscale eenheid, dat wil zeggen de in de vennootschappelijke jaarrekening van de deelnemers op te nemen belastinglast, is gecompliceerder. Een eenduidige voor alle gevallen bevredigende oplossing is hiervoor niet te vinden. De fiscale eenheid bestaat slechts fiscaalrechtelijk. Vennootschapsrechtelijk bezien hebben de deelnemers hun zelfstandigheid behouden. De rechtshandeling van het aangaan van de fiscale eenheid zal daarom aangevuld moeten worden met de afspraak tussen de deelnemende partijen over hoe de gezamenlijke belastinglast tussen de deelnemers zal worden verdeeld. Die verdeling is in ons land (in tegenstelling tot de VS) niet fiscaalrechtelijk opgelegd en moet civielrechtelijk nog worden geregeld. Door deze afspraken vroegtijdig (dat wil zeggen niet pas in het zicht van faillissement) te maken en vast te leggen kan wellicht voorkomen worden dat deze afspraken, ook al blijken ze achteraf nadelig voor schuldeisers te werken, als paulianeus kunnen worden bestempeld. Of deze afspraken echter altijd stand kunnen houden als ze getoetst worden aan de eisen van redelijkheid en billijkheid van het (nieuw) BW is onder omstandigheden twijfelachtig. Ook valt door het (tijdig) vastleggen van deze afspraken niet uit te sluiten dat onder omstandigheden niettemin sprake is van onrechtmatige verrijking.

De oplossing waarbij de moedermaatschappij optreedt als ware zij fiscus lijkt op het eerste gezicht de meest realistische. Daarbij worden de dochtermaatschappijen geen voordelen onthou- 


\section{MAB}

den of toegerekend, die ze als zelfstandig belastingplichtige lichamen zouden hebben genoten of juist niet zouden hebben genoten. De moedermaatschappij krijgt geen voordelen toegerekend ten detrimente van de dochters. De bij deze methode veronderstelde fiscale zelfstandigheid van de dochtermaatschappijen is echter naar de aard slechts een fictie. De dochtermaatschappijen kunnen niet hun eigen fiscale grondslagen kiezen, geen eigen 'belastingpolitiek' voeren en de gehanteerde interne verrekenprijzen behoeven, aangezien ze fiscaal irrelevant zijn, geenszins 'atarm's-length' te zijn. Daarom zal onder omstandigheden deze methode van verrekening evenmin te allen tijde de toets van redelijkheid en billijkheid kunnen doorstaan. De RJ heeft er dan ook verstandig aan gedaan in de ontwerp-Richtlijn 2.53 .5 slechts een opsomming van mogelijke verrekeningsmethoden te geven zonder een voorkeur uit te spreken.

\section{Noten}

1 M.A. van Hoepen, Anticipated and deferred corporate income tax in companies' financial statements, chapter 11 : Deferredtax accounting in group accounts, Deventer, 1981.

2 C.B. Bavinck, Faillissement en fiscale eenheid (Vpb), Weekblad (voor fiscaal recht), nr. 5597, 23 juni 1983, pp. 824-832.

3 K.T. Bruyn, De curator en de fiscale eenheid in de vennootschapsbelasting, Weekblad (voor fiscaal recht), nr. 5621 , 19 januari 1984, pp. 101-103.

4 J.J.M. Tempelaars, Fiscale eenheid en de belastingen over het resultaat in de jaarrekening, Maandblad voor Accountancy en Bedrijfshuishoudkunde, 59e jaargang, nr. 4, april 1985, pp. 180-185.

A.C. van Utteren, Fiscale eenheid en de belastingen over het resultaat in de jaarrekening (een reactie), Maandblad voor Accountancy en Bedrijfshuishoudkunde, 59 e jaargang, $\mathrm{nr} .9$, oktober 1985, pp. 388-391.
5 Tweede Kamer, Belastingvoorstellen, pp. 34-2014, 8 dec 1988.

6 F. van der Wel, Fiscale eenheid, groep en jaarrekening, Weekblad (voor fiscaal recht), nr. 5860, 16 maart 1989, pp. 337-346.

7 Richtlijnen voor de jaarverslaggeving, ontwerp-Richtlijn 2.53 .5 (aflevering 12, mei 1992).

8 Bijvoorbeeld R.P. Weber, The allocation of consolidated federal income tax liabilities with some related accounting and legal implications, Michigan, 1975

9 Richtlijnen voor de jaarverslaggeving, ontwerp-Richtlijn 2.03.103 (aflevering 9, juni 1990).

10 Richtlijnen voor de jaarverslaggeving, ontwerp-Richtlijn 2.53.512 (aflevering 12, mei 1992).

11 F. van der Wel, t.a.p. p. 345.

12 in dezelfde zin ook: H. Beckman, A.J. Bindenga en W.N. Meijer (red.), Compendium voor de jaarrekening, Alinea 4.7.6.(11) (aflevering 30, aug. 1992).

13 Richtlijnen voor de Jaarverslaggeving, ontwerp-Richtlijn 2.53.528 (aflevering 12, mei 1992).

14 Ook Bruyn (noot 3) wees hier reeds in 1984 op. 15 D.L. Crumbley : Factors in choosing a method of allocating tax advantages among affiliates. The Journal of Taxation, June 1969 , p. 347. Het is overigens opmerkelijk dat de in de VS te hanteren verrekeningsmethoden niet primair in de 'accounting principles' behandeld worden maar voorgeschreven in de belastingwetgeving, in casu Internal Revenue Service : Regulations, Section 1.1502-33 (d) (2). De belastingdienst in de VS fungeert hiermee als hoeder van de belangen van de minderheidsaandeelhouders van de (verliesgevende) dochtermaatschappij.

16 Nog weer een andere in de VS toegelaten variant is die waarbij het verlies consequent wordt verdeeld tussen 'producers and users of the loss', deze variant vertoont veel overeenkomst met de methode waarbij de moedermaatschappij als fiscus optreedt.

17 Uiteraard geldt dit slechts voor voordelen (en nadelen) tijdens het bestaan van de fiscale eenheid. Dit argument gaat zeker niet op voor de verrekening van zogenaamde voorvoegingsverliezen en voor verliescompensatie over het splitsingstijdstip van de fiscale eenheid heen. Een behandeling van deze (gecompliceerde) materie ontstijgt evenwel het bestek van deze bijdrage.

18 Let wel dat de RJ deze eis alleen stelt indien de gehele belastinglast aan de moedermaatschappij wordt toegerekend. 